\title{
Determinants of Green Banking Implementation in Emerging Country: Evidence from Vietnam Banks
}

\author{
Do Hoai Linh, $\mathrm{PhD}$ * \\ School of Banking and Finance, National Economics University, Vietnam \\ 207 Giai Phong Road, Hanoi, Vietnam \\ Nguyen Thi Hai Duong, PhD \\ Faculty of Insurance, National Economics University, Vietnam \\ 207 Giai Phong Road, Hanoi, Vietnam \\ Le Tran Ha Trang \\ School of Advanced Education Programs, National Economics University, Vietnam \\ 207 Giai Phong Road, Hanoi, Vietnam \\ Le Thi Khanh Ly \\ School of Advanced Education Programs, National Economics University, Vietnam \\ 207 Giai Phong Road, Hanoi, Vietnam \\ Ta Nguyen Lan Trang \\ School of Advanced Education Programs, National Economics University, Vietnam \\ 207 Giai Phong Road, Hanoi, Vietnam \\ Do Hue Anh \\ School of Advanced Education Programs, National Economics University, Vietnam \\ 207 Giai Phong Road, Hanoi, Vietnam
}

\begin{abstract}
With the purpose of examining which factors affecting on the implementation of 'Green Banking' in transitional countries, the research used in-depth interview and survey questionnaire with statistics analysis with the case of Vietnam banks. The results showed that in emerging country such as Vietnam, the level of 'Green Banking' implementation is most affected by Human determinant, followed by Strategy, Product \& Services, Culture and Technology determinant respectively. Based on findings, several implications were proposed to enhance the performance of these kind of environment friendly financial products in transitional country. By determining these factors, the banking sector in transitional countries will enhance the implementation of 'Green Banking' and achieve sustainable development in the context of escalating environmental contamination.
\end{abstract}

Keywords: Green Banking, Implementation, Emerging Country, Human

DOI: $10.7176 / \mathrm{EJBM} / 11-15-04$

Publication date:May $31^{\text {st }} 2019$

\section{Introduction}

The risk of global economic downturn combining with environmental crisis has raised the question about how to achieve sustainable development in organizations, especially in banking sector since it is an important financial resource of the economy (Thu Huong, 2013). In other words, both environment and banking sector take part in affecting the stability of economic growth. However, banks tend to concentrate on profits and neglect the benefits of environment, which makes it hard for banking sector to maintain sustainable development. Through many discussions, Green Banking is considered to be an effective model which balances profit with social environment. Nowadays, maintaining sustainable development based on Green Banking model is gradually becoming a common trend of many countries in the world. On the international market, Green Banking is widely recognized as it provides a solid development basis for banking systems. After the economic crisis of 2008, financial institutions have acknowledged the importance of Green Banking for sustainable growth. According to the report of International Finance Organization (IFC), 77 banks and financial institutions in developed countries agree not to finance projects with high environmental risks. Considering Vietnamese banks as a representative case of emerging countries, the awareness of commercial banks in Vietnam for environmental risk management is still limited and undeveloped. Green Banking activities have been implemented only in a small number of financial institutions; rarely do any banks fully implement this model. Most of previous studies carried out on Green Banking only synthesize the experiences of international countries, enlighten green services and activities in banks or short-term programs; yet certain implementation measures and determinants of implementation of Green 
Banking in commercial banks in developed countries, especially in Vietnam, have not been specified. It is essential to clarify this research gap. Our study aims to investigate factors, and their impacts on the implementation of Green Banking in commercial banks in Vietnam.

\section{Literature review}

Green banking is a concept where the banks show their concerns on protecting the environment by considering the sustainability of internal and external environment. The banks doing such type of activities is called ethical bank, green bank or sustainable bank. This type of banking is the modern platform and the model for future banks. As per the definition of the Indian Banks Association (IBA, 2014), Green Banking is defined as a normal bank which considers all factors related to environment and society with the purpose of protecting the environment as well as preserving natural resources. According to the International Institute for Sustainable Development (IIDS, 2016), Green Banking can be understood in two ways. In the broad sense, Green Banking means sustainable banks. In order to be sustainable, banks need to look at a big picture and put their interest in parallel with the benefit of society and the environment (Imeson and Sim, 2010). In the narrow meaning, Green Banking implies environmental actions, such as "green" activities not only inside but also outside the bank. For example, promoting online transaction methods, mobile banking or using ATM systems to customers to minimize the amount of papers, stationery and electrical equipment using in the bank. Moreover, banks also organize "green credit programs" or sponsoring for friendly environmental projects so as to partly reduce carbon pollution outside the bank (Singla and Arya, 2014). These green banks carry the daily banking activities with an additional mission which is taking care of the earth as well as the nature. Improving the technology uses, green project financing and altering the behaviors of customers not only in the banks but also in the society have always been the concerns of this type of banking. According to Greenbank report (2010), Green Banking has many beneficial roles to not only banks but also the society in saving the energy and resources, cost efficient, preventing the sustainable development of the economy from environmental factors, and aiming at protecting the environment as well as focusing on reducing the carbon footprint.

\subsection{External determinants of implementing 'Green Banking'}

2.1.1 Regulatory environment and government supporting

In the context of climate change and serious environmental pollution, sustainable development in general and in particular green economy is a suitable direction for the banking industry. Ma Jun, the Special Advisor to United Nations Environment on Sustainable Finance, believed governments and multilateral development banks (MDBs) to play a role in offering a strong incentive of helping the market allocate resources and "go green" financial system (Ma Jun, 2017). Linderberg and colleagues claimed, to begin with, governments, regulators and state banks of each country can diversify investment opportunities and resources by mobilizing private capital and organization for green investment. Besides, a green framework helps to transfer resources which has bad effects on environment to friendly environmental ones, leading businesses to expand and develop in long term. Additionally, green banking guidance from state banks also contribute to create a level play field by avoiding competitive distortions caused by risk assessment conducted only by some banks as well as decrease the credit default risks of banks' borrowers. (Linderberg et al., 2016). To react with government supporting, many prestige banks in developed countries have shown their commitment of combination of environmental factors with financing; enhancing recycling program and environmental events; focusing on energy efficient and alternatives. However, in developing countries, poor implementation of existing laws, shortage of promotions and inadequate from citizens results in low environmental management (Habib, 2010).

2.1.2 Socio - economic status and demand of sustainable development

Socio - economic issues have obvious influences on Implementing of "Green Banking". According to the report of the Organization for Economic Co-operation and Development (OECD), the social economic impacts related to environmental degradation are serious in developing country because of dependence on natural resources. These countries also are vulnerable by climate change, extreme weather, shortage of energy, food and water security. (OECD, 2012). Sharma insisted developing economy which is specified with overpopulation and globalization such as India, society is seriously affected by negative impacts of industrialization. Thus, seeking for sustainable development is necessary (Sharma, 2013). At this time, the banking sector will play an important role in providing financial resources for projects to achieve sustainable development. The responsibility and the importance of "Green Banking" to green projects, environmental reservation also increase.

2.1.3 Infrastructure enhancement of economy

Facilities and technical infrastructure play a role in branding, ensuring operational efficiency and quality of banking services. In particular, during 4.0 revolution which is taking place strongly in developing countries, the banking industry is also affected by the development of technology. This requires banks to focus on investing in facilities, upgrading equipment to keep pace with the development momentum and promptly launch new products and services in line with market demand. 


\subsubsection{Other determinants}

Other determinants such as culture, customer awareness and demand also show an impact in "Green Banking" deployment. The large number of customers who are familiar with smart apps and increasing development of technology are benefits to applying technologies to minimize the tradition work of banks. Currently, many banks offer policies to encourage customers to change customers' habits of using online services. On the other hand, its effects have not been yet examined. Chen suggested companies to develop green banking to have competitive advantages, to improve company image, to seek opportunities in new markets as well as to enhance their product value (Chen, 2010). However, Chen has not been examined the relationship between "Green Banking" and green image. According to Chang and Fong's research related to green products in Taiwan, they only found the result of customer's satisfaction and loyalty, not as the result of "Green Banking" activities (Chang and Fong, 2010).

\subsection{Internal determinants of implementing 'Green Banking'}

\subsubsection{Banks' strategy}

Strategy is an important part of organizational operations. Dharwal \& Agarwal point out green banking is a key in dealing with problems related to the credit, legal and reputation risk. The author makes some suggestion for "Green Banking" strategies like green mortgages, carbon footprint reduction, green finance products (Dharwal \& Agarwal, 2013) [14]. Stewart had emphasized on "go green" can improve the brand image and boost marketing. Green banking practices can render banks competitive advantages compared to competitors (Stewart, 2008). Ginovsky discussed about green buildings and its effect on implement "Green Banking". He suggested that a green building with large windows to allow natural light, solar energy system, many trế will improve the public and employee satisfaction (Ginovsky, 2009).

2.2.2 Human factors

To develop and implement "Green Banking”, about human factors, it is vital to concern about awareness, behavior and expertise. Along with enhancement of modern technology, e - banking to meet the users' needs, banks need to attract skillful human resources with not only expertise but also knowledge to catch up with the trend of high technology and "Green Banking". Additionally, banks should organize professional training programs to improve operational quality, limit transaction risks, raise awareness about responsibilities and work habits. Moreover, the internal control work as well as sanctions cannot be ignored.

2.2.3 Corporate culture

Positive behaviors of employees of the organization are able to increase efficiency of individuals and organization, which contributes to completing the goal of business. In fact, banks can motivate employees to comply with rules and loyalty and to be willing to help other colleagues. It will improve productivity and customer satisfaction while reducing cost and labor surplus. In addition, these activities also help banks to optimize their available resources and increase cohesion among members.

2.2.4 Banking products and services

Ginovsky had emphasized that banks should provide products which encourage the sustainable development. Green products and services can be divided in two main types: green banking activities and green credit activities (Ginovsky, 2009). According to the report "Green Financial Products and Services" of United Nations Environment Programme Finance Initiative (UNEP FI), green credit activities include green mortgage lending, green credit cards or green project funding. With green credit activities, the bank will offer attractive lending interest for the loans with the aim of environmental protection, limiting environmental and social risks. Green internal activities include banking operations such as using energy-saving electricity networks; use ATM systems, smart banking, internet banking, electronic transactions, online transactions; changing forms, traditional storage and communication tools to online to limit the use of printed documents and documents (UNEP FI, 2007). These types of products and services have brought great utility to customers. In many aspects such as transaction processing speed, unlimited time, space, low transaction costs, minimal transaction procedures.

2.2.5 Technology application in banking operations

Banks are initially focusing on developing online payment services, E-Banking transfer, online registration procedures and storing customer information on computers to limit wasteful resources (papers, electricity and water, ...). These services will give customers the habit of being environmentally friendly in banking operations and are more fully aware of the concept of 'Green Banking' when these activities can contribute to minimizing the impacts which are not good to the environment and ecosystem. In addition to supporting risk management, these services also help improve profitability and cost savings for banks. The development of technology will ensure safety and security for transaction activities, information storage, bank security, while improving efficiency and speed of processing.

2.2.6 Globalization and integration trend

One of the biggest concerns in the 21 st century is environmental protection and sustainable development in all sectors, including banks. In a rapidly changing market economy, with global integration, industries in general and companies in particular are very vulnerable to strict public policies and ministries. Strict laws as well as consumer 
boycott if any environmental issues are encountered. This also affects banks and financial companies in recovering investment. Therefore, banks need to make investments, loans to businesses in the field of environmental protection, using appropriate technology and management systems by bringing environmental and ecological aspects into their lending standards.

\section{Methodology}

This study used in-depth interview and survey questionnaire with statistics analysis. 500 questionnaires in total including employees, managers, directors working at commercial banks' branches in the north of Vietnam, out of which 474 were validated for further analysis. Besides, to obtain more detailed expertise from experts, the authors conducted in - depth interview with 5 managers and directors of commercial banks in Vietnam. The below figured is research framework:

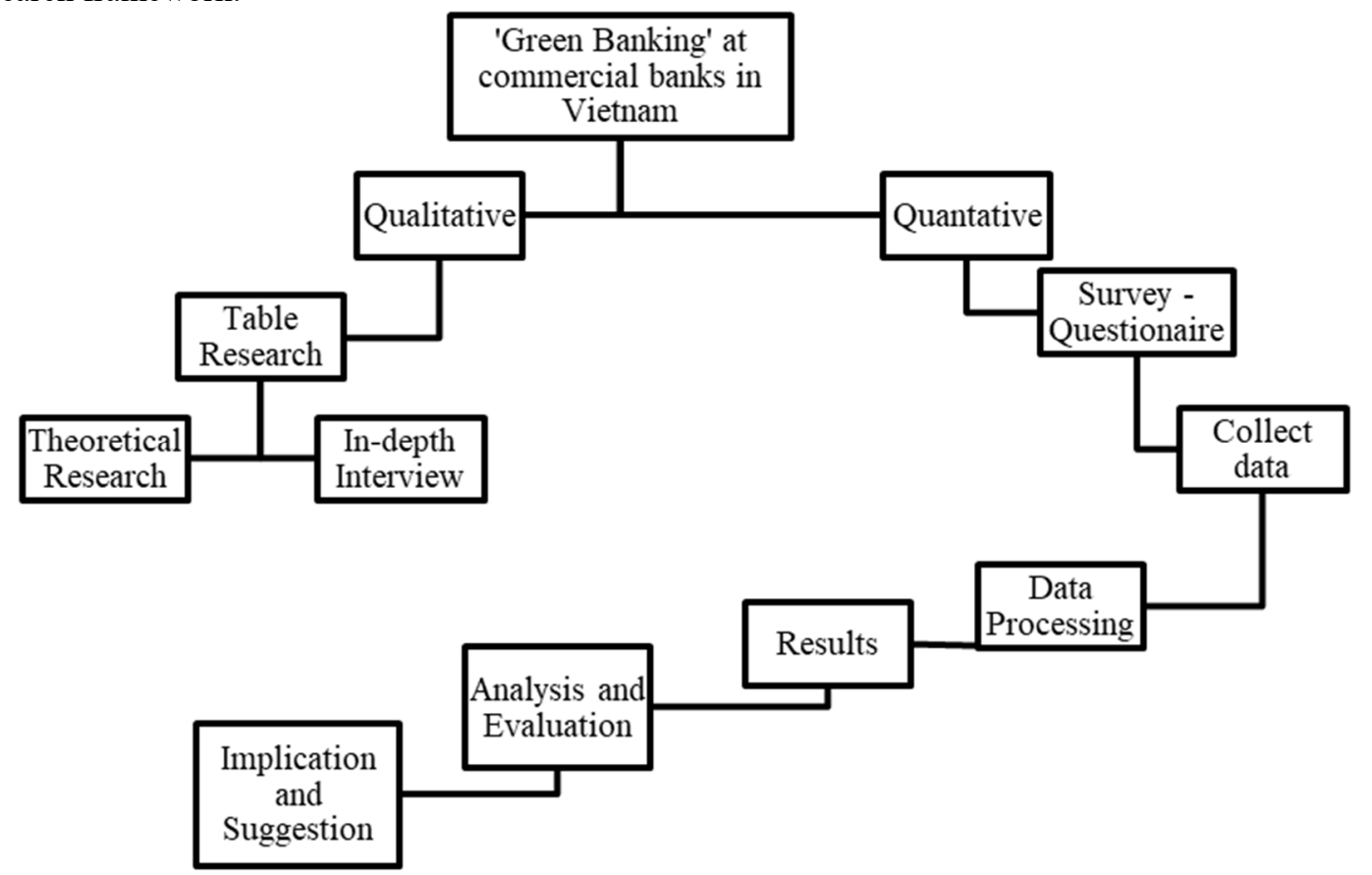

Figure 1: Research Framework

Source: Primary data obtained by the authors

\subsection{Questionnaire}

Questionnaire was designed based on Likert scale from "1 - Totally disagree" to "5 - Totally agree".

Sample: 500 people chosen including employees, managers, directors working at commercial banks' branches in the north of Vietnam. According to Bollen K.A (1989), the minimum sample rate is 5:1, which means that the minimum number of samples must be 5 times the number of observed variables. This study has 5 observable variables to assess the impact of factors affecting "Green Banking", so the group decided to select a sample size of 500 . The total number of research votes sent was 500 votes, in which, the valid votes are 474 votes. This data will be aggregated for further analysis.

\subsection{In-depth interview}

To obtain more detailed views from professors, the authors conducted in - depth interview with 5 managers and directors of commercial banks in Vietnam. The questions were designed based on questionnaire but more specific.

\section{Analytical Results}

Correlation analysis has been conducted to verify the relationship among quantitative variables through correlation coefficient Pearson (r). The correlation coefficients in the table below show the relationship among variables is relatively reasonable in both direction and strength. Specifically, all correlation coefficient values are greater than 0 , less than 0.8 , and have both positive and negative signs which reflect either positive or negative relationship. The relationship between dependent and independent variables has meaning without abnormal signs. In addition, the strength of the correlation coefficients ensures that there is no multi-collinearity phenomenon occurs when using linear regression model. Therefore, other statistics could be used to verify the relationship among variables. 
Table. 1: Correlation analysis

\begin{tabular}{|c|c|c|c|c|c|c|c|}
\hline \multicolumn{8}{|c|}{ Correlations } \\
\hline & & $\begin{array}{c}\text { Implementation } \\
\text { level }\end{array}$ & Strategy & Culture & $\begin{array}{c}\text { Product } \\
\& \\
\text { Services }\end{array}$ & $\begin{array}{l}\text { Technology } \\
\text { application }\end{array}$ & Human \\
\hline \multirow[t]{6}{*}{$\begin{array}{l}\text { Pearson } \\
\text { Correlation }\end{array}$} & $\begin{array}{l}\text { Implementation } \\
\text { level }\end{array}$ & 1.000 & .315 & .236 & .358 & .077 & .462 \\
\hline & Strategy & .315 & 1.000 & -.015 & .113 & -.282 & .038 \\
\hline & Culture & .236 & -.015 & 1.000 & .050 & -.053 & .007 \\
\hline & $\begin{array}{l}\text { Product } \quad \& \\
\text { Services }\end{array}$ & .358 & .113 & .050 & 1.000 & -.096 & .064 \\
\hline & $\begin{array}{l}\text { Technology } \\
\text { Application }\end{array}$ & .077 & -.282 & -.053 & -.096 & 1.000 & .090 \\
\hline & Human & .462 & .038 & .007 & .064 & .090 & 1.000 \\
\hline
\end{tabular}

Table 2 shows the descriptive statistics result. All variables have average (Mean) greater than 4, Culture variable has the highest mean (4.3815) while Technology Application variable has the lowest mean (4.1042). The lowest standard deviation is Culture variable at 0.47818 and the highest one is Technology Application at 0.61978. From these results, it can be said that questionnaires must have received many "agree" or "very agree" assessments from respondents.

Table. 2: Descriptive statistics

\begin{tabular}{|l|r|r|r|r|r|}
\hline \multicolumn{7}{|c|}{ Descriptive Statistics } \\
\hline & \multicolumn{1}{|c|}{$\mathbf{N}$} & \multicolumn{1}{c|}{ Minimum } & \multicolumn{1}{c|}{ Maximum } & \multicolumn{1}{c|}{ Mean } & \multicolumn{1}{c|}{ Std. Deviation } \\
\hline Strategy & 472 & 1.83 & 5.00 & 4.2721 & .51655 \\
\hline Culture & 472 & 1.00 & 5.00 & 4.3815 & .47818 \\
\hline Product \& Services & 472 & 1.58 & 5.00 & 4.1659 & .55963 \\
\hline Technology application & 472 & 2.00 & 5.00 & 4.1042 & .61978 \\
\hline Human & 472 & 1.00 & 5.00 & 4.3385 & .56976 \\
\hline Implementation level & 472 & 1.00 & 5.00 & 4.2163 & .60477 \\
\hline Valid N (listwise) & 472 & & & & \\
\hline
\end{tabular}


Table. 3: Model Summary

\begin{tabular}{|c|c|c|c|c|c|c|c|c|c|c|}
\hline \multicolumn{11}{|c|}{ Model Summary ${ }^{\text {b }}$} \\
\hline \multirow[t]{2}{*}{ Model } & \multirow[t]{2}{*}{$\mathbf{R}$} & \multirow{2}{*}{$\begin{array}{c}\mathbf{R} \\
\text { Square }\end{array}$} & \multirow{2}{*}{$\begin{array}{l}\text { Adjusted } \\
\text { R Square }\end{array}$} & \multirow{2}{*}{$\begin{array}{c}\text { Std. } \\
\text { Error of } \\
\text { the } \\
\text { Estimate }\end{array}$} & \multicolumn{5}{|c|}{ Change Statistics } & \multirow{2}{*}{$\begin{array}{l}\text { Durbin- } \\
\text { Watson }\end{array}$} \\
\hline & & & & & $\begin{array}{c}\text { R } \\
\text { Square } \\
\text { Change }\end{array}$ & F Change & df1 & df 2 & $\begin{array}{c}\text { Sig. F } \\
\text { Change }\end{array}$ & \\
\hline 1 & $.714^{\mathrm{a}}$ & .510 & .514 & .20861 & .510 & 25.483 & 5 & 466 & .000 & 1.481 \\
\hline \multicolumn{11}{|c|}{ a. Predictors: (Constant), CN, UDCN, SP, VH, CL } \\
\hline \multicolumn{11}{|c|}{ b. Dependent Variable: MDTK } \\
\hline
\end{tabular}

According to estimated model result, $\mathrm{R}$ Square $=0.510$, which means independent variables in the model could explain 51.0\% of overall level of implementing 'Green Banking' in commercial banks in Vietnam. That the estimated result is greater than $50 \%$ would be accepted in a model.

Table. 4: Coefficient of regression model of determinants of implementation 'Green Banking' in commercial banks in Vietnam

\begin{tabular}{|c|c|c|c|c|c|c|c|c|c|}
\hline \multicolumn{10}{|l|}{ Coefficients ${ }^{a}$} \\
\hline \multirow{2}{*}{ Model } & \multicolumn{2}{|c|}{$\begin{array}{l}\text { Unstandardized } \\
\text { Coefficients }\end{array}$} & \multirow{2}{*}{$\begin{array}{l}\begin{array}{l}\text { Standardized } \\
\text { Coefficients }\end{array} \\
\text { Beta }\end{array}$} & \multirow{2}{*}{$\mathrm{T}$} & \multirow{2}{*}{ Sig. } & \multicolumn{2}{|c|}{$\begin{array}{l}\text { 95\% Confidence } \\
\text { Interval for B }\end{array}$} & \multicolumn{2}{|c|}{$\begin{array}{l}\text { Collinearity } \\
\text { Statistics }\end{array}$} \\
\hline & $\mathrm{B}$ & $\begin{array}{l}\text { Std. } \\
\text { Error }\end{array}$ & & & & $\begin{array}{l}\text { Lower } \\
\text { Bound }\end{array}$ & $\begin{array}{l}\text { Upper } \\
\text { Bound }\end{array}$ & Tolerance & VIF \\
\hline Constant & -.418 & .388 & & -1.206 & .231 & -.984 & .148 & & \\
\hline Strategy & .304 & .128 & .346 & 2.375 & $.009 *$ & .173 & .447 & .909 & 1.109 \\
\hline Culture & .181 & .089 & .227 & 3.627 & $.042 * *$ & .076 & .286 & .994 & 1.036 \\
\hline $\begin{array}{l}\text { Product \& } \\
\text { Services }\end{array}$ & .198 & .075 & .319 & 2.641 & $.017 * *$ & .105 & .291 & .976 & 1.025 \\
\hline $\begin{array}{l}\text { Technology } \\
\text { Application }\end{array}$ & .183 & .097 & .183 & 1.886 & $.062 * * *$ & .022 & .344 & .903 & 1.124 \\
\hline Human & .275 & .084 & .462 & 3.274 & $.003 *$ & .198 & .352 & .983 & 1.023 \\
\hline
\end{tabular}

Notes. $* * *, * * *$ are statistically significant at $1 \%, 5 \%$ and $10 \%$ respectively

The table shows that Sig ratio of a slope coefficient which is greater than 0.05 will not be statistically significant at 5\% in significance level. From these results that Sig coefficient of independent variables including Strategy, Culture, Product \& Services and Human are less than 0.05, it can be said that independent variables are statistically significant at $5 \%$ in significance level. The Sig coefficient of Strategy and Human variables are less than 0.01 , which means these two variables are statistically significant at $1 \%$ in significance level. Technology application variables has Sig coefficient less than $0.1(0.062)$, which means this variable is statistically significant at $10 \%$ in significance level.

Diminutive order of the impact level of 5 determinants is (1) Human (standardized $\beta$ coefficient is .462), (2) Strategy (standardized $\beta$ coefficient is .346), (3) Products \& Services (standardized $\beta$ coefficient is .319), (4) Culture (standardized $\beta$ coefficient is .227), (5) Technology application (standardized $\beta$ coefficient is .183).

According to the regression model, standardized $\beta$ coefficient which is greater than 0 shows a positive relationship among independent variables in implementation 'Green Banking' in banks in Vietnam. Therefore, the level of implementation 'Green Banking' in commercial banks in Vietnam is mainly assessed by Human determinant. Meanwhile, Technology application is determinant having lowest impact on implementation 'Green 
Banking'.

The table shows that independent variables: Strategy, Culture, Products \& Services, Human and Technology application have great effects on implementation 'Green Banking' in commercial banks in Vietnam. All of the determinants are statistically significant and positively correlative to implementation 'Green Banking'. Coefficients of regression are greater than $0 . \mathrm{H} 0$ is rejected; $\mathrm{H} 1, \mathrm{H} 2, \mathrm{H} 3, \mathrm{H} 4$ and $\mathrm{H} 5$ are accepted. From these results, it can be said that all determinants mentioned above have a positive impact on the level of 'Green Banking' implementation in commercial banks in Vietnam.

The meaning of the slope B:

$+\mathrm{B} 1=0.304>0$ : when Strategy variable increases by 1 unit, the average implementation level increases by 0.304 units. The standard regression value of Strategy variable affects $34.6 \%$ on 'Green Banking' implementation in commercial banks.

$+\mathrm{B} 2=0.181>0$ : when Culture variable increases by 1 unit, the average implementation level increases by 0.181 units. The standard regression value of Culture variables affects $22.7 \%$ on 'Green Banking' implementation in commercial banks.

+ B3 $=0.198>0$ : when Product \& Services variable increases by 1 unit, the average implementation level increases by 0.198 units. The standard regression value of Product \& Services variable affects $31.9 \%$ on 'Green Banking' implementation in commercial banks.

+ B4 $=0.183>0$ : when Technology application variable increases by 1 unit, the average implementation level increases by 0.183 units. The standard regression value of Technology application affects $18.3 \%$ on 'Green Banking' implementation in commercial banks.

$+\mathrm{B} 5=0.275>0$ : when Human variable increases by 1 unit, the average implementation level increases by 0.275 units. The standard regression value of Human variable affects $46.2 \%$ on 'Green Banking' implementation in commercial banks.

The importance of variables which have a great effect on 'Green Banking' implementation in commercial banks in Vietnam is estimated through standardized regression values. The results show that the level of 'Green Banking' implementation is most affected by Human determinant, followed by Strategy, Product \& Services, Culture and Technology determinant respectively.

\section{Discussion and Conclusion}

The paper generates certain results with regard to the influence of determinants at implementing 'Green Banking' in commercial banks in Vietnam. Analyzing data from 474 employees and interviews with authorities, it is concluded that determinants have both positive and negative effects on 'Green Banking' implementation in banks in Vietnam. The most important result of this paper is the finding on the reality of implementing 'Green Banking' at commercial banks and level of influence of determinants on 'Green Banking' deployment.

From analytic results, it can be said that determinants have impacted positively on implementing 'Green Banking'. Strategy plays an important role in commercial banks. If each of the Vietnam banks has specific implementation strategies, which means they would have clear and principle objectives in environmental orientation and sustainable development. Banks will have the sense to not only provide green credit services that is oriented towards sustainable development, but also focus on making the best use of human resources, capital investment and technology application with a view to forming company culture that is friendly to environment. Besides, Human plays a part in implementing 'Green Banking'. If each of the leaders and employees has a rudimentary knowledge of 'Green Banking', they will develop an awareness of 'Green Banking' and make concerted efforts in orienting enterprises towards sustainable and environmentally- friendly development. Application of modern technology such as E-Banking is considered to be a chief priority for commercial banks to implement 'Green Banking'. That technology is well invested have a positive impact on success of 'Green Banking' deployment. A good technologic platform can act as a prime support of 'Green Banking' development. As a result, technology is assumed as an essential determinant that should be invested in order to improve commercial banking systems when there is an increase in the number of different competitive banks. By positive impacts which are pointed, business owners may take this into consideration during 'Green Banking' implementation process to orient their strategies towards sustainable development in short-term and long-term perspective.

However, the interview result with authorities shows a fact that although Vietnam commercial banks have already had awareness of importance of 'Green Banking', almost strategies are still not clearly and specifically made. The application of technology and provision of green products \& services are just a way to follow current trend at most of the commercial banks. Green services are not seen as a base for sustainable and environmentallyfriendly development objectives. 'Green Banking' is not considered to be a key target. Green growth is not a priority strategy that leaders made. Reason stems from the fact that there are not specific policies and documents about deployment of 'Green Banking' in Vietnam. Moreover, almost both leaders and staffs have not had awareness of sustainable development yet. This is why preparation for 'Green Banking' implementation in Vietnam commercial banks is not very effective. In spite of certain limitations, this study has a huge contribution 
in suggesting for Vietnamese banks in the developing orientation in general. The finding of determinant's impacts on 'Green Banking' implementation in Vietnam banks may form a ground for changes of leader's perception in both orienting and deploying 'Green Banking' in current situation in banks.

Commercial banks in Vietnam should have a clear and specific plan to orient development towards 'Green Banking' in a long run. Strategies need to be outlined in details with a view to deploying this new kind of bank step by step. To improve social and environmental risk management system, commercial banks should not only prevent projects which have negative effects on environment, but also deeply analyze standard ones that meet environmental requirements to avoid adverse effects. Besides, Vietnam commercial banks ought to stabilize and increase capital investment for environmentally friendly projects. Employees have a direct impact on 'Green Banking' implementation, therefore, focusing on developing human determinant is necessary. They need to be well-equipped with basic knowledge about 'Green Banking', sustainable development definition, and green growth policy to have ability to evaluate whether business projects meet environmental requirements or not. Highlevel leadership system also needs training in management faculty with a final view to increasing their awareness of sustainable development when implementing 'Green Banking'. Such investment in human being determinant is a long-term goal which can lead to cultural formation in each of the commercial banks in Vietnam. Advanced technology application that highly-qualified employees can apply should be pointed out in specific strategies. To improve electronic transactions installed with numerous benefits for customers, banks need to computerize credit system so that customers can diversify their purposes when using green products and services. As green credit, environmentally-friendly credit-granting projects... have not been widely distributed in Vietnam banks, new investment policies should be revealed to promote these kinds of green services instead of focusing only on diversifying. Furthermore, it is necessary for government to encourage multinational corporations to invest in modern technology such as artificial intelligence; prioritize research related to technologic upgradation to create a basic premise for 'Green Banking' implementation. Attracting foreign direct investment standardized with environmentally-friendly criteria is recommended to limit negative impacts on ambient environment. The government should keep tight control over licensing projects that meet all environmental requirements of commercial banks, and support banks by granting green capital. Besides, the Central bank should impose specific regulations on 'Green Banking' implementation and documents drew up about responsibilities of enterprises when granting capital. Finally, rewarding policy is necessary to encourage firms demanding of being granted capital for environmentally-friendly projects.

\section{Limitations and Further Study}

Despite efforts to collect data properly, the data compilation is not comprehensive in some aspects. However, findings are still based on good science. The analytical results and recommendations in this research are good reference that can be used for other studies on the influence level of determinants on implementing 'Green Banking' in commercial banks in Vietnam. By expanding sample size and incorporating more variables, the study could be more accomplished nationally and internationally.

The research could be extended by comparative method: taking historical perspectives and ask how "Green Banking" implementation at commercial banks significantly changed after a shift in awareness of top managers of sustainable development. Questions about ways to improve "Green Banking" implementation are also recommended while interviewing. This will provide significant information to analyze research results and suggest more useful solutions that are closely based on answers of leaders.

\section{References}

Thu Huong (2013). Ngân hàng xanh là nguồn lục để thực hiện tăng trưởng xanh. Retrieved from: $\mathrm{http}$ //www.taichinhdientu.vn/tai-chinh-trong-nuoc/ngan-hang-xanh-la-nguon-luc-de-thuc-hien-tang-truongxanh-129916.html

Bollen, K.A. (1989) Structural Equations with Latent Variables. John Wiley and Sons, Inc., New York.

Chang, N. J., \& Fong, C. M. (2010). Green product quality, green corporate image, green customer satisfaction, and green customer loyalty. African Journal of Business Management, 4(13), 2836.

Dharwal, M., \& Agarwal, A. (2013). Green Banking: An Innovative Initiative for Sustainable Development.

Ginovsky, J. (2009). Green banking - Inside and out. Community Banker, 30-32

Greenbank Report. (2010, July). The basics of green banking. Retrieved at http://greenbankreport.com/greenbank-report/the-basics-of-green-banking/

Habib, S M A (2010), “Green Banking Initiative: Opportunities for Bangladesh”, Bank Parikrama, Vol. XXX \& XXXVI, September 2010, March 2011, BIBM, Dhaka

Imeson, 2010 Imeson, M. and Sim, A (2010). Sustainable Banking: Why Helping Communities and Saving the Planet is Good for Business? SAS White Paper. Issued by SAS Institue Inc. World Headquaters.

Indian Banks Association, 2014. Green banking innovations; Indian bank association. http://www.theindianbanker.co.in/html/sto_5.htm. 
Lindenberg, N. (2016). Green Banking Regulation - Setting out a Framework.

Ma Jun. (2017, October 13). Green finance and the role of government. Retrieved from GlobalCapital: https://www.globalcapital.com/article/b154vmms2vw39c/green-finance-and-the-role-of-goverment

Nguyen Thi Minh Chau (2016). Thục trạng hoạt động ngân hàng xanh tại Việt Nam. Retrieved from https://gec.edu.vn/tong-hop/thuc-trang-hoat-dong-ngan-hang-xanh-tai-viet-nam.html

OECD. (2012). Green Growth and Developing Countries. OECD.

Sharma, K. (2013). Green Banking in India: A Roadmap to Success. IBMRD's Journal of Management and Research

Singhal, K., Singhal, K., \& Arya, M. (2014). Green banking: An overview. Asian Journal of Multidisciplinary Studies, 2(6), 196-200.

Thai Hang, (2014). Enhancng efficiency of social and environment risk management: key factor to develop Green banking, Retrieved from http://tapchitaichinh.vn/kinh-te-vi-mo/yeu-to-then-chot-de-ngan-hang-xanh-phattrien-ben-vung-84054.html

Thanh, T., \& Hoang, Y. (2015). Green Bank: International Experiences and Vietnam Perspectives. State Bank of Vietnam. Retrieved from http://www.sbv.gov.vn

Vikas Nath, Nitin Nayak \& Ankit Goel (2014), Green Banking Practice - A Review, International Journal of Research In Business Management.

UNEP FI. (2007). Green Financial Products and Services. Retrieved from United Nations Environment Programme Finance Initiative: https://www.unepfi.org/fileadmin/documents/greenprods_01.pdf 